\title{
Influencing Factors of Investment Scale of Power Grid Enterprises
}

\author{
Xia Liyu $^{1 *}$, He Wan ${ }^{1}$, Zhang Qian and Zeng Bingxin ${ }^{1}$ \\ ${ }^{1}$ State Grid Energy Research Institute, Beijing, 102209, China
}

\begin{abstract}
Investment is the key driving force for the sustainable growth of power grid enterprises. The rationality of investment scale directly determines the investment efficiency, and affects the quality of enterprise growth. The internal and external environment of investment management of power grid enterprises is constantly changing. Scientific judgment of the importance of various influencing factors can provide strong support for the determination of investment scale. In this paper, the factors affecting the investment scale of power grid enterprises are divided into economic and social development, product industry development, enterprise operation and management, and power grid operation and development. Representative indicators are selected for analysis, and the influence degree of various influencing factors is judged by correlation coefficient test and variable importance evaluation method. The empirical results show that the enterprise management and power grid operation and development have greater impacts on the investment scale. The influence of internal factors is greater than that of external factors.
\end{abstract}

\section{Introduction}

Investment, construction and operation of power grid is the core business of power grid enterprises. Power grid enterprises undertake the basic mission of ensuring safe, economic, clean and sustainable power supply, and are large backbone enterprises related to the lifeline of national economy and national energy security. The investment scale is the annual operation and development goals and investment plans that dominate the overall situation of power grid enterprises based on the comprehensive balance and overall optimization of the core resources and development needs of power grid enterprises. At present, the internal and external environment of power grid enterprise investment management is constantly changing. Scientific judgment of the importance of various influencing factors can provide strong support for the determination of investment scale and the increase of investment efficiency.

The internal and external environment of investment scale management of power grid enterprises is undergoing profound and complex changes. The investment scale is affected by many factors, including macroeconomic environment, industry development trend, product development trend, changes in competitive relationship, enterprise development status.

In terms of macro-economic environment, enterprises need to increase the scale of investment when the momentum of economic development is good, the State implements loose control policies, and the living standards of residents are improved. In terms of industry development trend, when the market capacity of energy and power industry is large, enterprises need to increase the investment scale. When the industry competition is increasing, enterprises can speed up the upgrading of traditional business, cultivate new business forms and new models, and increase the competitive advantage by optimizing and adjusting the investment structure. In terms of product development trend, the functions and forms of products or services of the company can meet the needs of customers, and the sales methods can attract and retain customers. The investment scale of such products or services should be increased. In terms of the change of competitive relationship, when the market share, regional performance and sales trend of enterprise products or services are good in the competitive environment, the enterprise needs to increase the investment scale. When the main competitors adjust the production and operation strategy, mode, price and channel of products or services, they need to conduct detailed benchmarking analysis, predict the market competitive relationship, adjust the investment scale or structure, and optimize the operation mode and investment control mode. In terms of enterprise development, when the enterprise's operating efficiency, operating efficiency and customer service level are high, the enterprise needs to increase the investment in hard power and soft power to further promote the development of the enterprise and promote the realization of enterprise strategy and planning. 


\section{Correlation analysis of influencing factors}

The investment of power grid enterprises is composed of capital investment and cost investment. This paper divides the influencing factors into four dimensions: Economic and social development, product industry development, enterprise operation and management, and power grid operation and development.

Economic and social development factors represent the level of regional economic and social development, covering two aspects of economic development and social development. They can be represented by industrial added value, total import and export, the proportion of added value of the tertiary industry, total retail sales of social consumer goods, urban registered unemployment rate and other indicators. Product industry development factors represent the development level of the energy and power enterprises, which can be represented by industry power generation, power consumption of the whole society and other indicators.
Enterprise management factors represent the level of enterprise plan implementation and operation development, covering planning implementation, operation efficiency and operation efficiency. They can be represented by the enterprise power supply, the completion of business expansion, operating income, total profit, asset liability ratio, controllable expenses, economic value added, return on net assets, number of employees, total labor productivity and other indicators. The factors of power grid operation and development represent the level of regional economic and social development, which can be represented by line loss rate, power generation capacity, power generation equipment capacity, maximum peak valley difference and other indicators.

Based on the data of some power grid enterprises from 2015 to 2019, the linear correlation coefficients between current indicators and lagging indicators of various influencing factors and investment scale are calculated respectively, and the significance test is carried out. The results are shown in Table 1.

\begin{tabular}{|c|c|c|c|c|c|c|c|}
\hline \multirow{2}{*}{ Dimension } & \multirow{2}{*}{ Indicator } & \multicolumn{3}{|c|}{ Capital investment scale } & \multicolumn{3}{|c|}{ Cost investment scale } \\
\hline & & $\mathbf{T}$ & T-1 & T-2 & $\mathbf{T}$ & T-1 & T-2 \\
\hline \multirow{5}{*}{$\begin{array}{c}\text { Economic } \\
\text { and social } \\
\text { development }\end{array}$} & Industrial added value & $0.828 * *$ & $0.833 * *$ & $0.837 * *$ & $0.748 * *$ & $0.761 * *$ & $0.764 * *$ \\
\hline & Total import and export & $0.635 * *$ & $0.629 * *$ & $0.620 * *$ & $0.469 * *$ & $0.482 * *$ & $0.461 * *$ \\
\hline & $\begin{array}{l}\text { Proportion of added value } \\
\text { of the tertiary industry }\end{array}$ & 0.009 & -0.003 & -0.005 & $-0.234^{*}$ & $-0.256 * *$ & $-0.252 * *$ \\
\hline & $\begin{array}{c}\text { Total retail sales of social } \\
\text { consumer goods }\end{array}$ & $0.852 * *$ & $0.845 * *$ & $0.843 * *$ & $0.715^{* *}$ & $0.698 * *$ & $0.690 * *$ \\
\hline & $\begin{array}{c}\text { Urban registered } \\
\text { unemployment rate }\end{array}$ & $-0.200^{*}$ & -0.180 & -0.164 & -0.029 & -0.020 & -0.006 \\
\hline \multirow{2}{*}{$\begin{array}{c}\text { Product } \\
\text { industry } \\
\text { development }\end{array}$} & Industry power & 0.65 & 0.668 & $0.665 * *$ & 0.566 & 0.579 & $0.595 * *$ \\
\hline & $\begin{array}{c}\text { Power consumption of the } \\
\text { whole society }\end{array}$ & $0.773 * *$ & $0.773 * *$ & $0.768 * *$ & $0.651 * *$ & $0.658 * *$ & $0.669 * *$ \\
\hline \multirow{10}{*}{$\begin{array}{l}\text { Enterprise } \\
\text { operation } \\
\text { and } \\
\text { management }\end{array}$} & Enterprise power supply & $0.836^{* *}$ & $0.835 * *$ & $0.836 * *$ & 0.740 & $0.759 * *$ & $0.782 * *$ \\
\hline & $\begin{array}{c}\text { Completion of business } \\
\text { expansion }\end{array}$ & $0.848 * *$ & $0.827 * *$ & $0.765 * *$ & $0.777 * *$ & $0.742 * *$ & $0.629 * *$ \\
\hline & Operating income & $0.839 * *$ & $0.843 * *$ & $0.849 * *$ & $0.775 * *$ & $0.764 * *$ & $0.752 * *$ \\
\hline & Total profit & $0.807 * *$ & $0.807 * *$ & $0.779 * *$ & $0.658 * *$ & $0.631 * *$ & $0.617 * *$ \\
\hline & Asset liability ratio & 0.097 & 0.111 & 0.132 & $0.234 *$ & $0.255^{* *}$ & $0.243^{*}$ \\
\hline & Controllable expenses & $0.837 * *$ & $0.846^{* *}$ & $0.817 * *$ & $0.747 * *$ & $0.709 * *$ & $0.730 * *$ \\
\hline & Economic value added & $0.598 * *$ & $0.617 * *$ & $0.620 * *$ & $0.542 * *$ & $0.504 * *$ & $0.588 * *$ \\
\hline & Number of employees & $0.622 * *$ & $0.629 * *$ & $0.605 * *$ & $0.685 * *$ & $0.683 * *$ & $0.601 * *$ \\
\hline & Total labor productivity & $0.380 * *$ & $0.369 * *$ & $0.370 * *$ & 0.187 & 0.186 & $0.202 *$ \\
\hline & Return on net assets & $0.476^{* *}$ & $0.490 * *$ & $0.505 * *$ & $0.485^{* *}$ & $0.471 * *$ & $0.466^{* *}$ \\
\hline \multirow{4}{*}{$\begin{array}{l}\text { power grid } \\
\text { operation } \\
\text { and } \\
\text { development }\end{array}$} & Line loss rate & -0.171 & -0.152 & -0.142 & $-0.205^{*}$ & $-0.195^{*}$ & $-0.199 *$ \\
\hline & Power generation capacity & $0.784 * *$ & $0.788 * *$ & $0.782 * *$ & $0.691 * *$ & $0.715 * *$ & $0.733 * *$ \\
\hline & $\begin{array}{l}\text { Power generation } \\
\text { equipment capacity }\end{array}$ & $0.738 * *$ & $0.721 * *$ & $0.706 * *$ & $0.642 * *$ & $0.636^{* *}$ & $0.645^{* *}$ \\
\hline & $\begin{array}{l}\text { Maximum peak valley } \\
\text { difference }\end{array}$ & $0.827 * *$ & $0.825 * *$ & $0.815 * *$ & $0.692 * *$ & $0.701 * *$ & $0.696 * *$ \\
\hline
\end{tabular}

Note: "*" means to pass the test at the significance level of $1 \%$, and $" * "$ means to pass the test at the significance level of $5 \%$.
There is no significant correlation between the proportion of added value of the tertiary industry, the lag index of urban registered unemployment rate, asset liability ratio, line loss rate and capital investment scale. 
The correlation between the current index of urban registered unemployment rate and capital investment scale passes the test at the significance level of 5\%. The correlation between the other influencing factors and capital investment scale passes the test at the significance level of $1 \%$ It has been tested.

There is no significant correlation between urban registered unemployment rate, total labor productivity index in the current period and lag index in the first period and cost investment scale. The correlation between the proportion of added value of the tertiary industry in the current period, asset liability ratio index in the current period and lag index in the second period, total labor productivity lag index in the first period, line loss rate and cost investment scale passes the inspection at the significant level of $5 \%$. The correlation between the other factors and cost investment scale passed the test at the significance level of $1 \%$.

Table 2. Importance assessment of influencing factors

\begin{tabular}{|c|c|c|c|c|c|c|c|}
\hline \multirow{2}{*}{ Dimension } & \multirow{2}{*}{ Indicator } & \multicolumn{3}{|c|}{ Capital investment scale } & \multicolumn{3}{|c|}{ Cost investment scale } \\
\hline & & $T$ & T-1 & T-2 & $\mathbf{T}$ & T-1 & T-2 \\
\hline \multirow{5}{*}{$\begin{array}{c}\text { Economic } \\
\text { and social } \\
\text { development }\end{array}$} & Industrial added value & 457.40 & 463.26 & 397.91 & 3.87 & 4.35 & 6.12 \\
\hline & Total import and export & 55.22 & 112.69 & 82.10 & 1.01 & 1.07 & 0.76 \\
\hline & $\begin{array}{l}\text { Proportion of added value } \\
\text { of the tertiary industry }\end{array}$ & I & I & / & 0.72 & 0.85 & 0.44 \\
\hline & $\begin{array}{l}\text { Total retail sales of social } \\
\text { consumer goods }\end{array}$ & 333.29 & 378.41 & 392.78 & 3.39 & 3.23 & 3.73 \\
\hline & $\begin{array}{l}\text { Urban registered } \\
\text { unemployment rate }\end{array}$ & 88.09 & / & l & I & / & I \\
\hline \multirow{2}{*}{$\begin{array}{c}\text { Product } \\
\text { industry } \\
\text { development }\end{array}$} & Industry power generation & 95.60 & 81.57 & 51.71 & 0.79 & 1.16 & 1.11 \\
\hline & $\begin{array}{c}\text { Power consumption of the } \\
\text { whole society }\end{array}$ & 129.37 & 129.37 & 206.57 & 2.52 & 3.01 & 2.07 \\
\hline \multirow{10}{*}{$\begin{array}{l}\text { Enterprise } \\
\text { operation } \\
\text { and } \\
\text { managemen }\end{array}$} & Enterprise power supply & 413.44 & 533.13 & 626.71 & 4.69 & 5.59 & 7.40 \\
\hline & $\begin{array}{c}\text { Completion of business } \\
\text { expansion }\end{array}$ & 397.77 & 280.58 & 100.64 & 8.89 & 4.78 & 3.07 \\
\hline & Operating income & 628.73 & 614.77 & 588.18 & 10.13 & 9.41 & 5.27 \\
\hline & Total profit & 113.04 & 218.83 & 130.22 & 1.26 & 3.45 & 2.04 \\
\hline & Asset liability ratio & I & 1 & / & 0.55 & 0.31 & 0.54 \\
\hline & Controllable expenses & 754.98 & 544.75 & 342.28 & 13.89 & 8.61 & 8.05 \\
\hline & Economic value added & 107.79 & 33.59 & 74.37 & 0.28 & 0.84 & 1.01 \\
\hline & Number of employees & 81.41 & 59.30 & 36.23 & 4.55 & 3.54 & 2.69 \\
\hline & Total labor productivity & 63.23 & 46.57 & 24.37 & / & / & / \\
\hline & Return on net assets & 55.19 & 13.94 & 6.59 & 0.90 & 0.17 & 0.18 \\
\hline \multirow{4}{*}{$\begin{array}{l}\text { power grid } \\
\text { operation } \\
\text { and } \\
\text { development }\end{array}$} & Line loss rate & 7 & I & 7 & 0.61 & 0.40 & 0.18 \\
\hline & Power generation capacity & 243.53 & 192.72 & 286.39 & 3.12 & 5.77 & 4.45 \\
\hline & $\begin{array}{l}\text { Power generation } \\
\text { equipment capacity }\end{array}$ & 166.47 & 59.28 & 78.97 & 1.20 & 1.97 & 2.52 \\
\hline & $\begin{array}{c}\text { Maximum peak valley } \\
\text { difference }\end{array}$ & 356.39 & 536.65 & 477.04 & 3.66 & 4.49 & 3.22 \\
\hline
\end{tabular}

Excluding the indicators of insignificant influencing factors, the paper takes capital investment scale and cost investment scale as dependent variables, and the current indicators and lagging indicators of influencing factors as independent variables to build a random forest model. The importance of each index is evaluated by the

\section{Importance assessment of influencing factors}

Variable importance evaluation is a special intermediate product produced in the process of modeling random forest model. Its principle is to investigate the contribution of each independent variable to each tree in the random forest, and then calculate the average value to compare the contribution of each variable. This value can show the importance of the independent variable, because if the random noise is added, the accuracy of the data will decrease greatly, which indicates that the independent variable has a great influence on the prediction results of the samples, and further indicates that the importance is relatively high. increase of error caused by the replacement of index data with white noise data. The results are shown in Table 2.

The more the error caused by an influencing factor increases, the greater the influence of the index on the accuracy of model prediction and the greater the importance of the index. The Importance assessment of variables in random forest model can only be used to 
evaluate the importance of each index in the same model, because the dimension of dependent variables varies from different models. As the size of capital investment is larger than that of cost investment, the overall error increases significantly.

Taking 80 as the judgment threshold, the factors that are relatively less important to capital investment scale are the current index of total import and export volume and the second lagging index, the second lagging index of industrial power generation, the lagging index of economic added value, the lagging index of staff number, the lagging index of total labor productivity, the rate of return on net assets and the lagging index of power generation equipment capacity.

Taking 1 as the judgment threshold, the factors that are relatively less important to cost investment scale are the second phase index of total import and export lagging behind, the proportion of the added value of the tertiary industry, the current index of industrial power generation, the asset liability ratio, the current index of economic added value and the first phase index lagging behind, the rate of return on net assets and the line loss rate.

\section{Conclusion}

Through the calculation of correlation coefficient test and variable importance evaluation method, it can be found that for capital investment scale and cost investment scale, the most influential factors are the company management and power grid operation and development, while the less influential factors are economic and social development and product industry development. Overall, development investment scale of each unit is affected by internal factors more than external factors.

\section{References}

[1] Zhang Q., Xia L.Y. (2019) Optimization of investment management mode of power grid enterprises. China power enterprise management, 16: 88-89.

[2] Song L.L., Wang Z.S., Wu J.N., Sun Y.R. (2020) Construction of performance management system of special funds for ecological and environmental protection -- from the perspective of comprehensive budget management. Friends of accounting, 24: 36-41.

[3] Lu Y.F.. (2020) Preliminary study on the integration of technology and knowledge of budget comprehensive performance management. Theoretical exploration, 6: 23-33.

[4] Tu S.J, Huang housheng, Wang Ling. (2020) Research on internal control of scientific research funds management under the background of "deregulation, management and service" -- Based on comprehensive budget performance management. Friends of accounting, 12: 77-83.
[5] Yang Y. (2020) Exploration and practice of comprehensive budget control system of CT Group. Finance and accounting, 10: 24-27.

[6] Chen H., Huang H.M., Wang H.Y. (2017) Research on the motivation of the annual business goal forecast of Listed Companies. Financial and accounting bulletin, 26: 48-50.

[7] Yang B.Z., Xue T., Wang Y.B. (2015) Innovation and application of comprehensive budget management in chuanhua group. Finance and accounting, 13: 18-22.

[8] Tang G.Q. (2014) Discussion on enterprise operation control and statistical analysis mode. China Statistics, 4: 39-40. 